\title{
Integrin $\alpha 9$ gene promoter is hypermethylated and downregulated in nasopharyngeal carcinoma
}

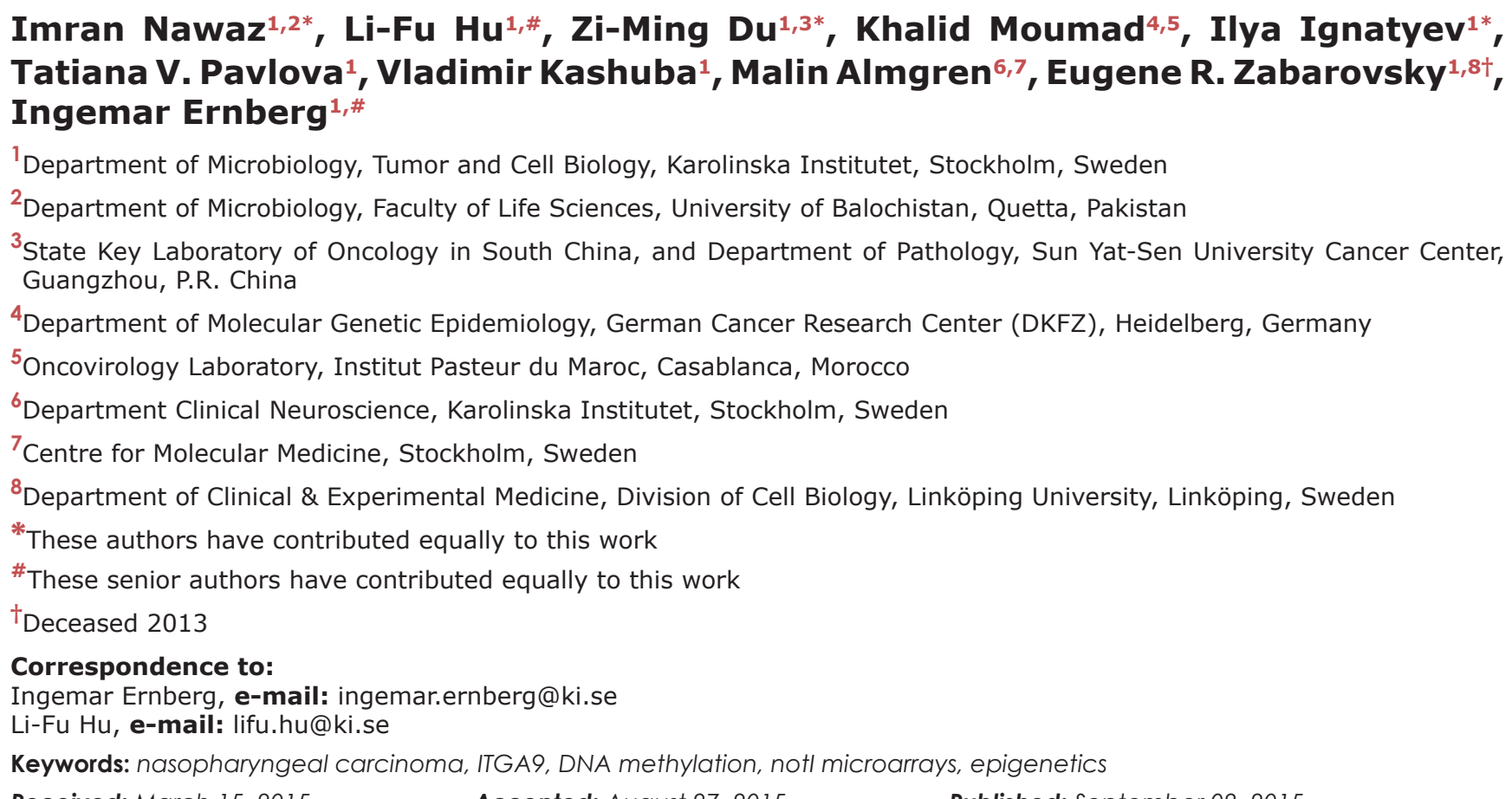

\section{ABSTRACT}

Epigenetic silencing of tumor suppressor genes (TSGs) by promoter methylation can be an early event in the multi-step process of carcinogenesis. Human chromosome 3 contains clusters of TSGs involved in many cancer types including nasopharyngeal carcinoma (NPC), the most common cancer in Southern China. Among ten candidate TSGs identified in chromosome 3 using NotI microarray, ITGA9 and WNT7A could be validated. 5'-aza-2' deoxycytidine treatment restored the expression of ITGA9 and WNT7A in two NPC cell lines. Immunostaining showed strong expression of these genes in the membrane and cytoplasm of adjacent control nasopharyngeal epithelium cells, while they were weakly expressed in NPC tumor cells. The ITGA9 promoter showed marked differentially methylation between tumor and control tissue, whereas no differentially methylation could be detected for the WNT7A promoter. The expression level of ITGA9 in NPC tumors was downregulated 4.9-fold, compared to the expression in control. ITGA9 methylation was detected by methylation specific PCR (MSP) in $56 \%$ of EBV positive NPC- cases with $100 \%$ specificity. Taken together, this suggests that ITGA9 might be a TSG in NPC that is involved in tumor cell biology. The possibility of using ITGA9 methylation as a marker for early detection of NPC should further be explored.

\section{INTRODUCTION}

Nasopharyngeal carcinoma (NPC) is a malignant tumor that arises in the surface epithelium of the posterior wall of the nasopharynx [1]. Its clinical presentation, epidemiology, and histopathology are different from typical squamous cell carcinomas of the head and neck [2]. NPC has a marked ethnic and geographic distribution. Specifically, its most common form, WHO type III is highly prevalent in Southern 
China, Southeast Asia, North Africa and Greenland, and shows a close to $100 \%$ prevalence of Epstein-Barr virus (EBV) in the tumor cells [3-7]. Regardless of the geographic distribution, NPC is suggested to result from the contribution and interplay of at least three distinctly different factors including environmental, genetic as well as EBV infection [8].

NPC patients in stages I and II of the disease have a significantly longer overall survival compared with those in stages III and IV. The five-year survival rate for stage III or IV patients is only around 40 to $50 \%$, while it can be as high as $95 \%$ for stage I or II patients [9-11]. Because of non-specific local symptoms and the inconvenience of full clinical examination of the nasopharynx, approximately $70 \%$ of NPC patients are only diagnosed when the tumor has reached an advanced stage with a poor prognosis $[3,10,12]$. Thus, early diagnosis of NPC is essential to achieve satisfactory treatment outcome. Finding biomarkers for detection of NPC at an early stage and monitoring recurrent tumor would contribute significantly to improve survival and guide the choice of subsequent therapy, particularly in the high incidence regions.

Changes in DNA methylation play an important role in both normal development and differentiation as well as cancer and several other diseases [13]. Alterations in DNA methylation with resulting aberrant activation of oncogenes or inactivation of certain TSGs is a key event in cancer development $[14,15]$. It has recently been suggested that cancer can be initiated by an epigenetic process before any mutations [16]. These TSGs were shown to be involved in fundamental pathways, such as apoptosis, DNA damage repair, tumor invasion and metastasis, cell cycle control and intracellular adhesion [17]. Silencing of potential TSGs by aberrant methylation of $\mathrm{CpG}$-rich promoter regions seems to be a key mechanism in NPC carcinogenesis [18-20]. It might be useful as a powerful means for the early diagnosis of NPC [21, 22]. The establishment of methylation based techniques for the early diagnosis of cancer will increase the chances for treatment and improve the survival rate.

Several approaches that allow high-throughput analyses of multiple $\mathrm{CpG}$-rich regions in gene promoters were recently developed, including methylation specific oligonucleotide microarrays, restriction landmark genomic scanning, and differential methylation hybridization [23-27]. Loss of heterozygosity ( $\mathrm{LOH}$ ) and cytogenetic studies earlier showed that frequent changes in chromosome 3 are common in many tumors, harboring several TSGs [28]. A NotI microarray developed by our group provides another possibility to search for methylation related genes in chromosome 3 [29]. The main idea of the approach is that the NotI restriction enzyme cuts only unmethylated CpG pairs inside the recognition sequence of the enzyme (5'-GCGGCCGC-3'). Only a small fraction $(0.1-0.5 \%)$ of the human genome contains NotI restriction sites, often located to CpG-islands [30]. Thus by using NMAs (glass microarrays with attached NotI-sequence tagged DNA fragments) we could compare the methylation status of control and malignant cells at the genomic level.

In this study, using chromosome 3 NMA, 188 putative TSGs were examined in NPC tumors and cell lines, and by subsequent analysis ITGA9- and WNT7A- control regions were shown to be hypermethylated and downregulated.

\section{RESULTS}

\section{Screening for potentially methylated genes in NPC using NotI microarrays}

NotI microarrays were performed to screen the potentially methylated genes in chromosome 3 in NPC. Genomic DNA from three NPC tumor biopsies (T9, T10 and T18), two control nasopharyngeal epithelial tissues (N1 and N2), three NPC cell lines (CNE1, TWO3 and C666-1) and one control nasopharyngeal epithelium derived cell line NP69 were used for this screening. Ten genes (ALDH1L1, BCL6, EPHB3, FGD5, FGF12, ITGA9, NUDT16P, RBSP3, WNT7A and ZIC4) were identified showing reduced signal in NPC samples as compared to control samples suggesting methylation or deletion of these genes in NPC (Table 1). To investigate the methylation status of these genes and possible correlation with gene downregulation, methylation specific PCR (MSP) and quantitative real time PCR (Q-PCR) were then performed. On the basis of the correlations found between the MSP and Q-PCR results two genes i.e. ITGA9 and WNT7A were selected for further validation and investigation.

\section{Demethylation and restoration ITGA9 and WNT7A expression in NPC cell lines by demethylating reagent 5 '-aza-C}

To investigate whether demethylating reagent 5 '-aza-C could demethylate ITGA9 and WNT7A promoters, NPC C666-1, CNE1, TWO3 cell lines and control nasopharyngeal epithelium derived cell line NP69 were treated with $10 \mu \mathrm{M}$ of the $5^{\prime}$-aza-C for $96 \mathrm{~h}$, and then MSP was performed to detect methylation status of ITGA9 and WNT7A. It was observed that the CpGrich regions in the promoter of ITGA9 and WNT7A were demethylated in NPC cell lines after 5 '-aza-C treatment by MSP, compared with untreated cells (Figure 1A \& 2A). A comparison of ITGA9 expression in NP69 and C666-1 cell lines showed that the expression level of ITGA9 mRNA was downregulated in NPC C666-1 $(6.4 \pm 0.1$ fold) as compared to control cell line (Figure 1B).

Furthermore Q-PCR was then performed to detect ITGA9 and WNT7A mRNA expression (Figure 2C \& 2D) in $5^{\prime}$-aza-C treated and untreated NPC CNE1 and TWO3 cell lines. The expression level of ITGA9 mRNA was upregulated in NPC CNE1 and TWO3 after 5'-aza-C 
Table 1: Screening for potentially methylated genes in NPC using NotI microarrays

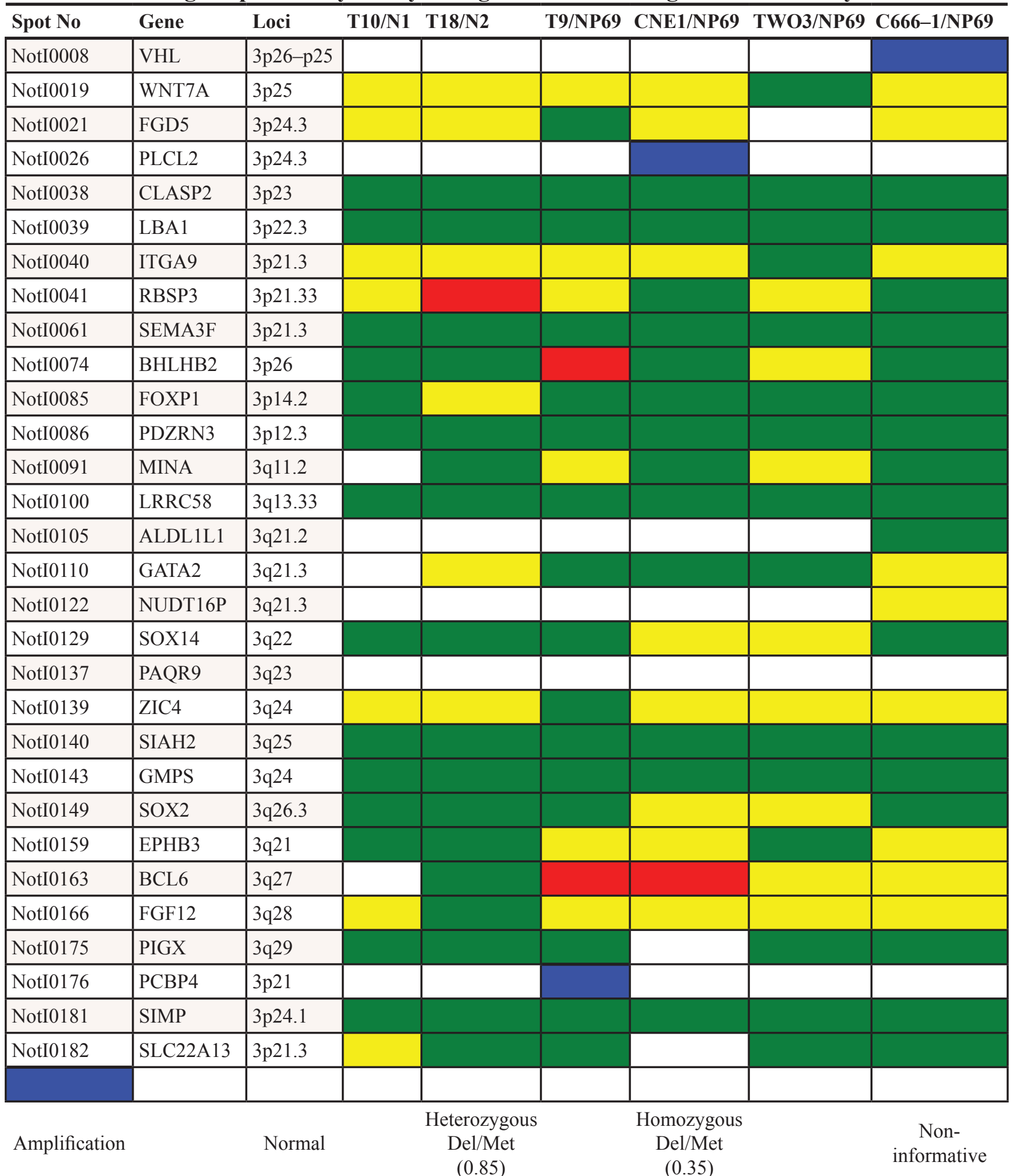

NotI microarrays were performed on genomic DNA from three NPC biopsies (T), two control nasopharyngeal epithelial tissues (N), three NPC cell lines and one cell line derived from control nasopharyngeal epithelium. A representative selection of genes is shown. Key to the different shades used in the cells is given at the bottom of the table. 
A

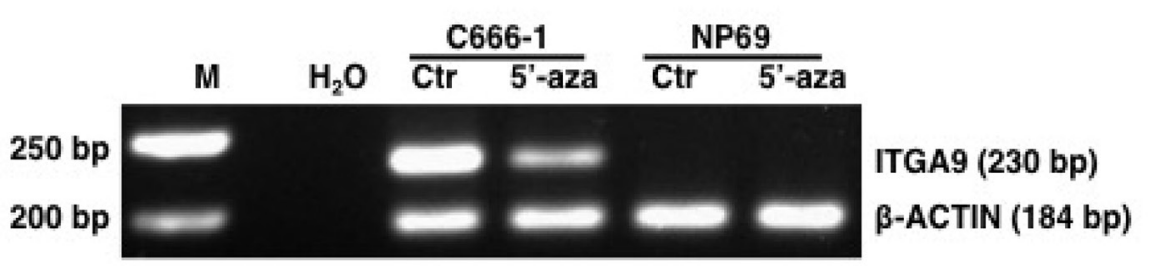

B

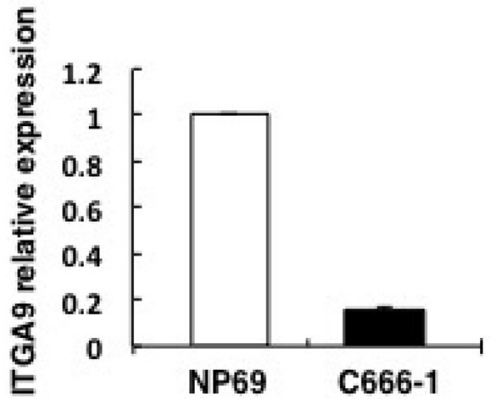

Figure 1: ITGA9 promoter is demethylated by demethylation reagent 5 '-aza-C in NPC C666-1 cell line where its expression is also downregulated. A. Methylation status of ITGA9 analyzed in control nasopharyngeal epithelium derived cell line NP69 and NPC C666-1 cell line treated with 5'-aza-C by MSP. B. mRNA expression status of ITGA9 analyzed in control nasopharyngeal epithelium derived cell line NP69 and NPC C666-1 cell line by Q-PCR.

A

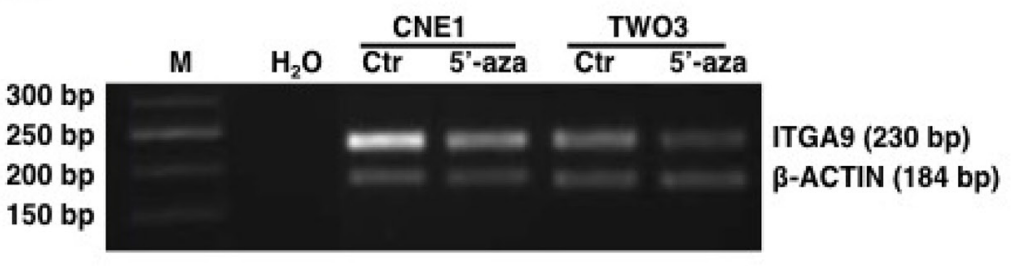

B

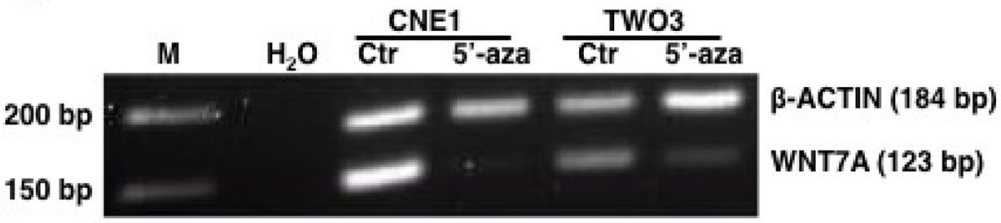

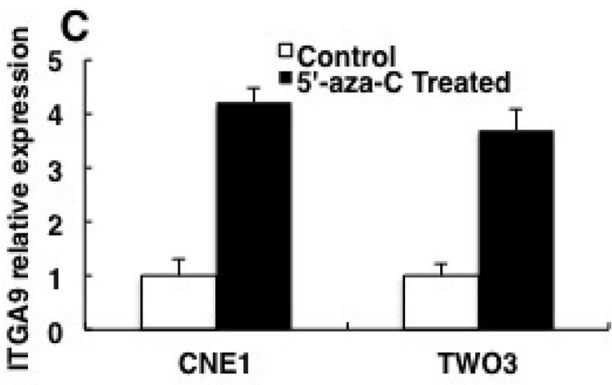

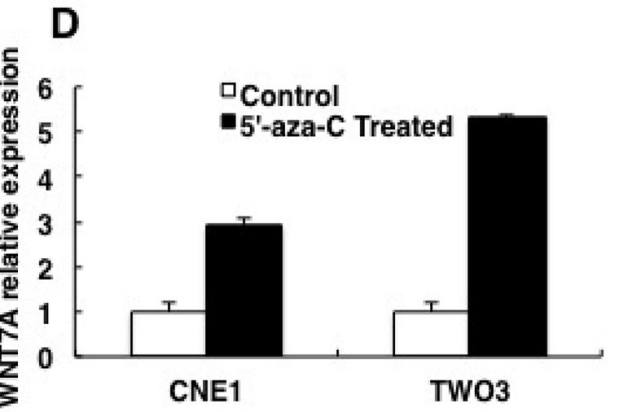

Figure 2: ITGA9 and WNT7A are restored by demethylation reagent $\mathbf{5}$ '-aza-C in NPC cell lines. Methylation status of ITGA9 A. and WNT7A B. analyzed in NPC CNE1 and TWO3 cell lines treated with 5'-aza-C by MSP. mRNA expression status of ITGA9 C. and WNT7A D. analyzed in 5'-aza-C treated and untreated NPC cell lines CNE1 and TWO3 by Q-PCR.

treatment $(4.2 \pm 0.3$ fold; $3.8 \pm 0.3$ fold respectively) as compared to untreated controls. The expression level of WNT7A was also upregulated in NPC CNE1 and TWO3 after 5 '-aza-C treatment $(3.1 \pm 0.2$ fold; $5.6 \pm 0.1$ fold respectively) as compared to untreated controls. Thus demethylating reagent 5'-aza-C could restore the expression of ITGA9 and WNT7A in NPC cell lines. This suggests that the downregulation of ITGA9 and WNT7A in NPC cell lines could be due to hypermethylation of promoters of these genes and not because of deletion of these genes in these cell lines.

\section{Downregulation of ITGA9 and WNT7A were found in NPC samples by immunostaining}

Immunostaining was performed to evaluate the expression of ITGA9 and WNT7A proteins in three cases of NPC tumor cells and adjacent control nasopharyngeal epithelium. Strong expression of ITGA9 (Figure 3A) and WNT7A (Figure 3B) was observed in membrane and cytoplasm of adjacent control nasopharyngeal epithelium cells, while weak or no expression of ITGA9 and WNT7A was observed in NPC tumor cells. This suggests that 


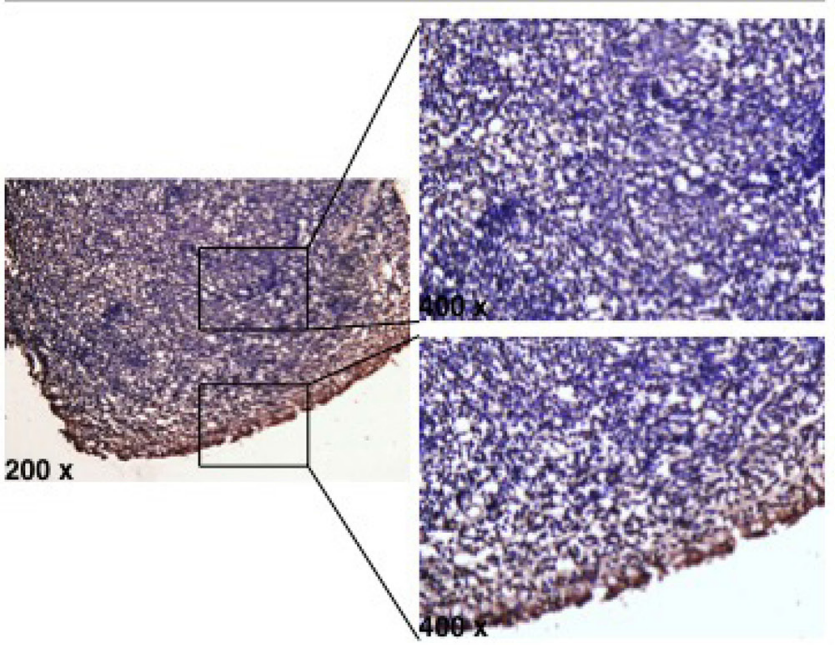

B

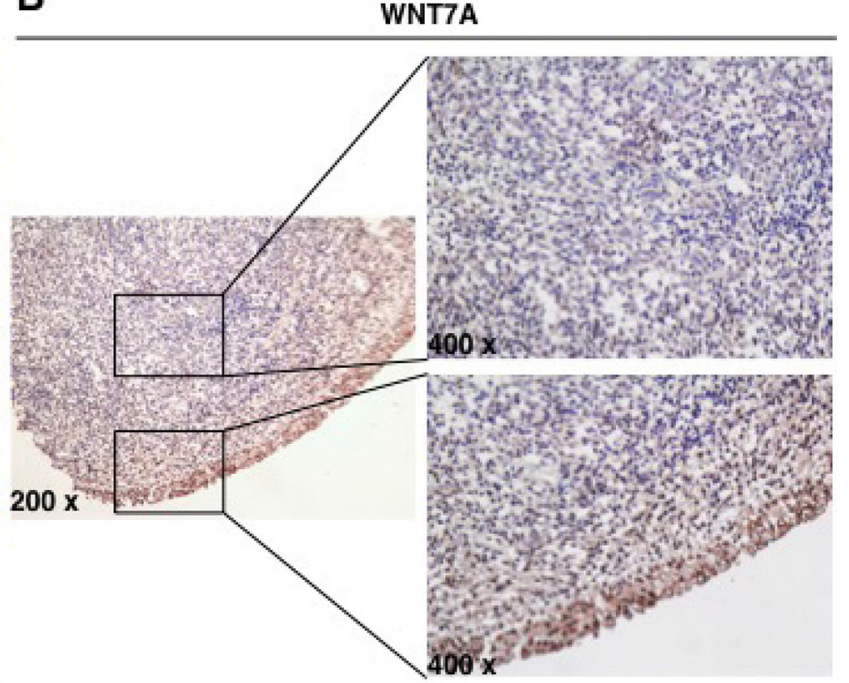

Figure 3: ITGA9 and WNT7A are downregulated in NPC clinical samples. Expression of ITGA9 A. and WNT7A B. evaluated in NPC tumor cells and adjacent control nasopharyngeal epithelium by immunostaining.

ITGA9 and WNT7A are downregulated in NPC tumors as compared to normal cells.

\section{Hypermethylation of ITGA9 and WNT7A in NPC}

The methylation status of ITGA9 and WNT7A promoters in NPC tumor biopsy samples was investigated by sequencing of clones after bisulfite conversion. A CpG-rich region in the promoter of ITGA9 gene was investigated (Figure 4A). This region containing $11 \mathrm{CpG}$ sites and was sequenced in nine NPC biopsies (NPC-1, NPC-2, NPC-5, NPC-6, NPC-547, NPC-562, NPC-581, NPC-586 and NPC-587) and six control nasopharyngeal epithelia biopsy (NNE-1, NNE-2, NNE-3, NNE-7, NNE-10 and NNE-20) (Figure 4B). This CpG-rich region in ITGA9 promoter was partially methylated in all NPC samples, whereas only a few $\mathrm{CpG}$ sites were partially methylated in the control samples. To investigate the methylation status of WNT7A, sequencing of the clones derived from bisulfite converted DNA was performed at a CpG-rich region in its promoter (Figure 5A). This region contained $84 \mathrm{CpG}$ sites. Four NPC biopsies (NPC-1, NPC-2, NPC-5 and NPC-6) and three control nasopharyngeal epithelia biopsy (NNE-3, NNE-7 and NNE-10) were sequenced (Figure 5B). This CpG-rich region was partially methylated in the four NPC samples. There was virtually no methylation in the two control samples (NNE-3 and NNE-10) while one control sample (NNE-7) showed some methylation at several $\mathrm{CpG}$ sites. Taken together these results suggested that particularly ITGA9 could be a candidate TSG in NPC worthy of further analysis.

\section{Hypermethylation of ITGA9 confirmed in NPC samples by pyrosequencing of the bisulfite converted tissue DNAs}

Two sub regions with high density CpGs in the ITGA9 control region were analyzed with pyrosequencing of the bisulfite converted tissue DNA. Two pyrosequencing assays (Pyro-S1 and Pyro-S2) targeted two different sets of CpGs that were located in the same region that was subjected to the sequencing of the clones derived from bisulfite converted DNAs as shown (Figure 4A). Pyro-S1 contained four CpGs. Three out of the four CpGs in pyro-S1 and all three CpGs covered by pyro-S2 overlapped with the CpGs used for sequencing the bisulfite converted DNA driven clones. Five biopsies (NPC-547, NPC-562, NPC-581, NPC-586 and NPC-587) and two control nasopharyngeal epithelia biopsies (NNE-1 and NNE-2) were sequenced with this method (Figure 6). The majority of the CpGs in ITGA9 gene promoter were partially methylated in all the NPC samples, while they were unmethylated in the control samples.

\section{Downregulation of ITGA9 in NPC tissue samples confirmed by Q-PCR}

Q-PCR was performed to detect ITGA9 expression in four control epithelial tissues (NNE2, NNE4, NNE5 and NNE7) and three NPC samples (NPC2, NPC3 and NPC4) (Figure 7A). The average expression level of ITGA9 in NPC tumors and in control epithelial tissues was as $4.0 \pm 1.3$ in NPC vs. $20.0 \pm 5.1$ in the control samples, respectively (Figure 7B). ITGA9 expression was 


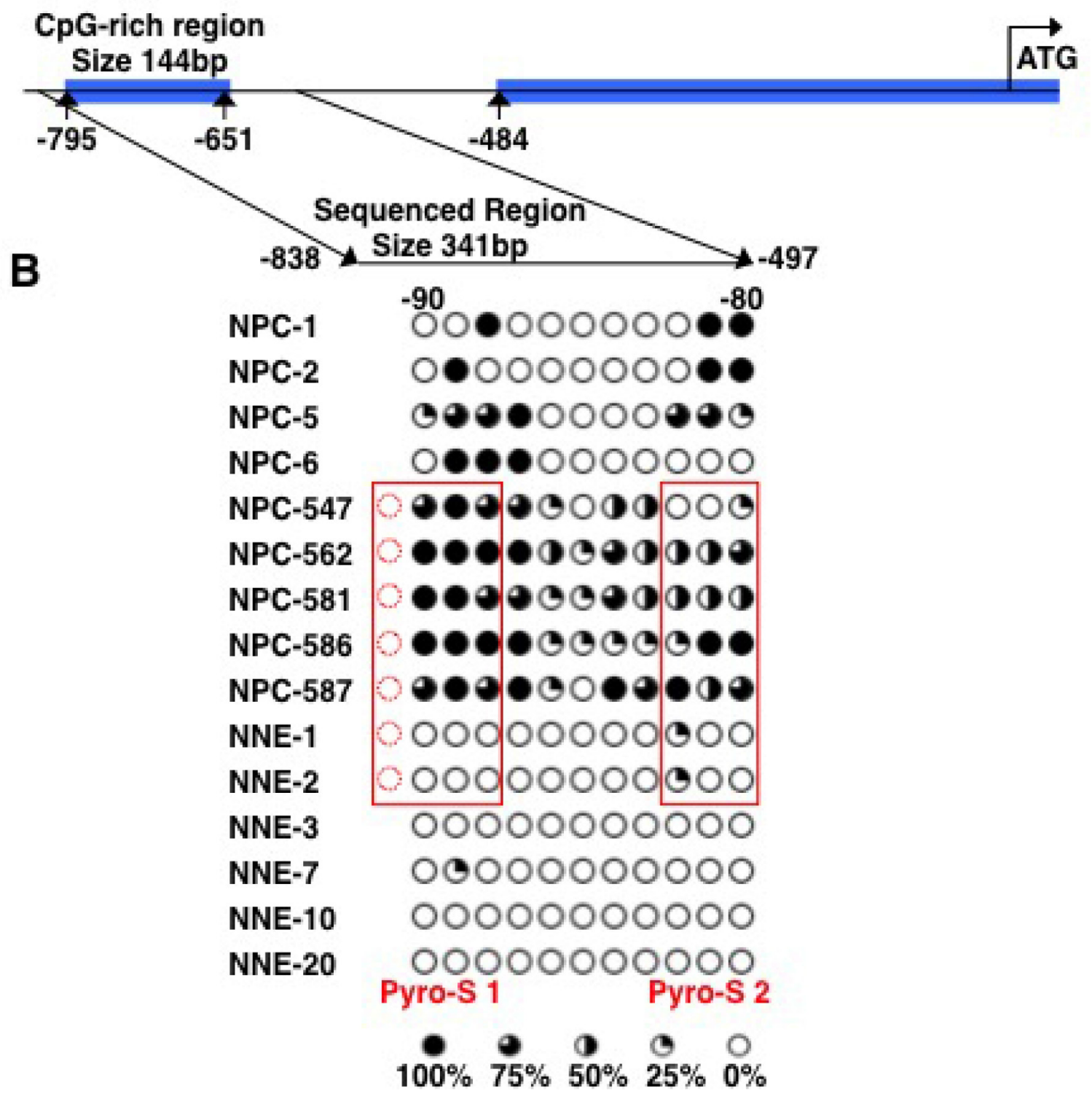

Figure 4: ITGA9 is differentially hypermethylated in NPC clinical samples. A. Schematic representation of ITGA9 gene and location of the CpG-rich regions in its promoter. B. Eleven $\mathrm{CpG}$ sites in the ITGA9 promoter analyzed by sequencing the clones derived from bisulfite converted DNA. Five to ten clones were sequenced for each sample. Open and filled circles represent unmethylated and methylated $\mathrm{CpG}$ sites, respectively. Circles are filled according to the percentage of clones with methylation of the CpG sites. The samples marked with red boxes were used also for the sequence analyses of bisulfite converted DNA by pyrosequencing assays (see figure 6).

downregulated in NPC tumor samples as compared to control nasopharyngeal epithelium.

Screening of methylation in ITGA9- and WNT7A-promoters in NPC biopsy samples from Morocco using MSP

Methylation specific PCR was used to screen DNA from 36 EBV positive NPC biopsy samples and 18 non-cancerous control samples from Morocco in order to determine the methylation status of ITGA9 and WNT7A. ITGA9 methylation was detected by MSP in 56\% (20/36) of NPC DNA samples with 100\% specificity (0/18 of non-cancerous control; Figure $8 \mathrm{~A})$. WNT7A methylation was detected by MSP in $69 \%$ $(25 / 36)$ of NPC DNA samples with $83 \%$ specificity ( 3 out of 18 in non-cancerous control; Figure 8B). These results suggest that ITGA9 could be a TSG in NPC and promoter hypermethylation could be one mechanism for ITGA9 downregulation in NPC. This might also suggest that ITGA9 could be used as an early detection marker for NPC. 


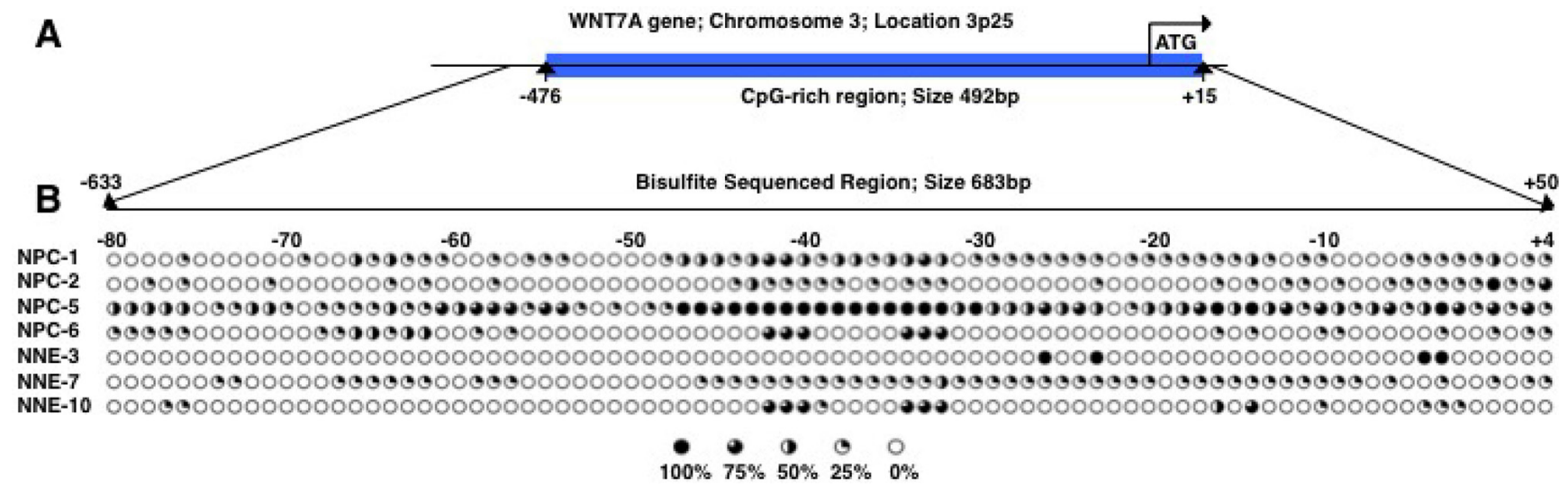

Figure 5: WNT7A is partially methylated in NPC clinical samples. A. Schematic representation of WNT7A gene and the location of a CpG-rich region in its promoter. B. Eighty-four CpG sites in WNT7A promoter were analyzed by sequencing the clones derived from bisulfite converted DNA. Five to ten clones were sequenced for each sample. Open and filled circles represented unmethylated and methylated $\mathrm{CpG}$ sites, respectively. Circles are filled according to the percentage of clones with methylation of the $\mathrm{CpG}$ sites.

\begin{tabular}{|c|c|c|c|c|c|c|c|}
\hline \multirow[b]{2}{*}{$\begin{array}{l}\text { NPC-547 } \\
\text { NPC-562 } \\
\text { NPC-581 } \\
\text { NPC-586 } \\
\text { NPC-587 } \\
\text { NNE-1 } \\
\text { NNE-2 }\end{array}$} & \multicolumn{4}{|c|}{ ITGA9 Pyro-S 1} & \multicolumn{3}{|c|}{ ITGA9 Pyro-S 2} \\
\hline & $\begin{array}{c}-91 \\
0 \\
0 \\
0 \\
0 \\
0 \\
0 \\
0\end{array}$ & $\begin{array}{r}-90 \\
0 \\
0 \\
0 \\
0 \\
0 \\
0 \\
0\end{array}$ & $\begin{array}{r}-89 \\
0 \\
0 \\
0 \\
0 \\
0 \\
0 \\
0 \\
0\end{array}$ & $\begin{array}{c}-88 \\
0 \\
0 \\
0 \\
0 \\
0 \\
0 \\
0\end{array}$ & $\begin{array}{cc} & -82 \\
: & 0 \\
: & 0 \\
: & 0 \\
: & 0 \\
: & 0 \\
: & 0 \\
: & 0\end{array}$ & $\begin{array}{c}-81 \\
0 \\
0 \\
0 \\
0 \\
0 \\
0 \\
0\end{array}$ & $\begin{array}{c}-80 \\
0 \\
0 \\
0 \\
0 \\
0 \\
0 \\
0\end{array}$ \\
\hline
\end{tabular}

Figure 6: ITGA9 is differentially hypermethylated in NPC clinical samples. Methylation status of two subsets of CpG dinucleotides present in one CpG-rich region in ITGA9 gene promoter investigated by sequencing the bisulfite converted DNA using two pyrosequencing assays. Pyro-S1 and pyro-S2 contained four and three $\mathrm{CpG}$ sites respectively (see figure 4B). Open and filled circles represent unmethylated and methylated $\mathrm{CpG}$ sites, respectively. Circles are filled according to the fraction of sequences methylated at the CpG sites.

\section{DISCUSSION}

NPC shows several unique features among tumors; its regional very high incidence in Southern China and surrounding countries and its strong association with EBV [31]. The effort has been intense to identify possible susceptibility genes and regional environmental factors, as well as to understand the role of EBV in NPC pathogenesis. Integration of these facts will help in developing prevention, improving diagnosis and treatment [32].

The development of NPC involves the accumulation of multiple genetic changes affecting certain tumor suppressor genes (TSG) or oncogenes thus promoting the clonal evolution of the neoplastic cell, like in many other cancers [33]. TSGs are suggested to play a key role in the transformation of nasopharyngeal epithelial cells into malignant ones [19, 34, 35]. Similarities of patterns in the chromosomal abnormalities have been reported in the NPC from different geographical regions [33]. Chromosome 3 p21.3 was the first tumor suppressive region mapped in NPC [36]. This region was shown to contain several TSGs [28, 37-39]. This suggests that inactivation of certain TSGs on chromosome 3 by mutations or epigenetic modifications might play a critical role in NPC [40].

In NPC, a vast number of TSGs are silenced by epigenetic mechanisms, primarily by promoter hypermethylation [41, 42]. It is highly interesting that EBV-infection is associated with extensive DNA methylation in EBV carrying malignancies, also recently demonstrated in EBV-associated gastric cancer [42, 43]. A comprehensive knowledge of hypermethylated and downregulated TSGs is not only important for the development of clinical strategies of NPC prevention and therapy, but hypermethylated TSGs can also be used as diagnostic biomarkers for NPC risk assessment, early detection and prognosis [41]. Many key TSGs for instance p53 and retinoblastoma $(\mathrm{Rb})$ that are frequently reported to be mutated in $50 \%$ of all other tumors have been shown to be wild-type in NPC $[44,45]$. p16 and Ras association domain family member 1A (RASSF1A) were the first TSGs that were reported to be hypermethylated 

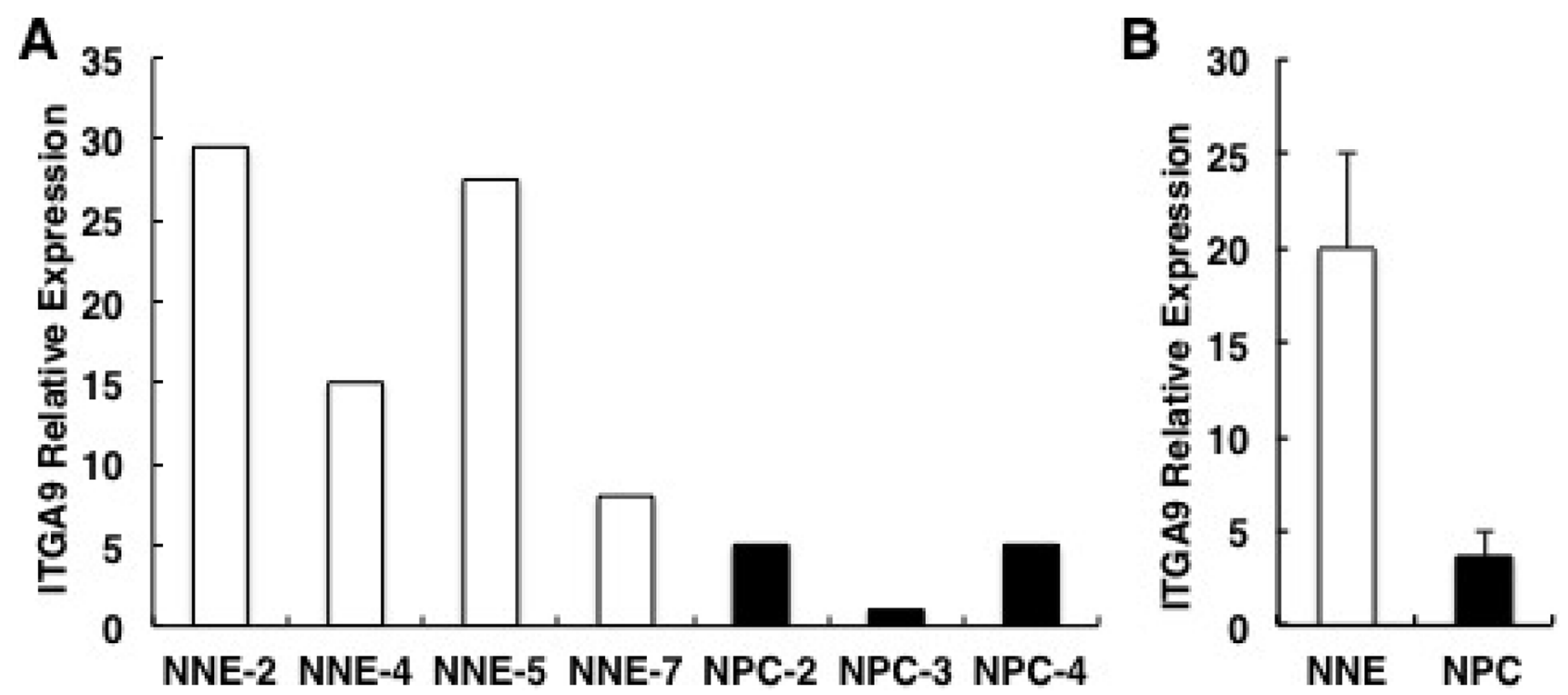

Figure 7: ITGA9 mRNA is downregulated in NPC biopsies. A. ITGA9 mRNA expression analyzed by Q-PCR in three NPC tissue $(\mathrm{T})$ and four control epithelial tissue samples $(\mathrm{N})$ B. The average downregulation of ITGA9 mRNA expression level comparing the three tumors versus four control tissues (from A).

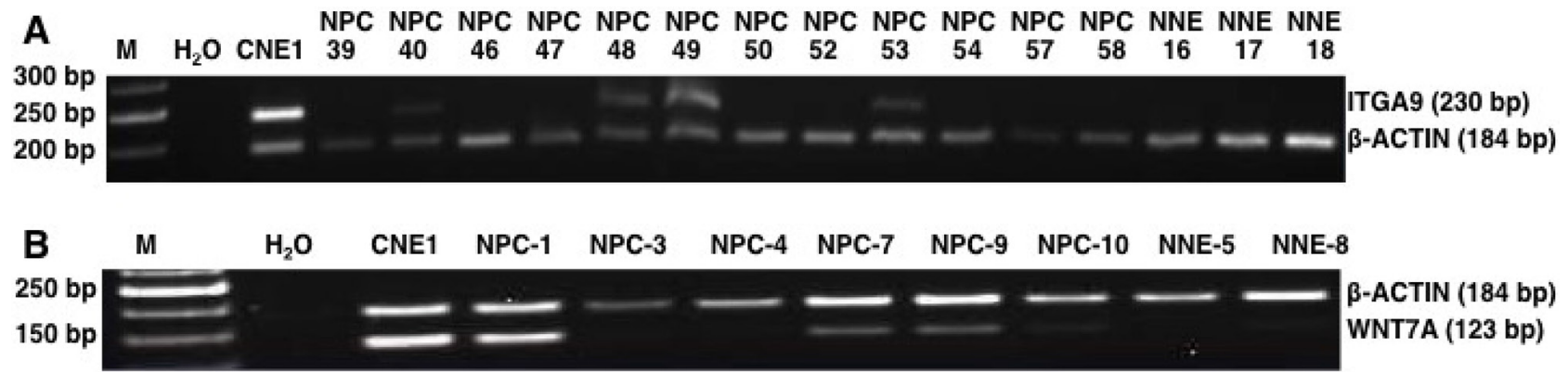

Figure 8: MSP analysis of NPC biopsies and non-cancerous control samples from Morocco. Methylation status of ITGA9 A. and WNT7A B. investigated in an independent cohort of NPC biopsy and control DNA samples by MSP. NPC: tumor; NNE: control nasopharyngeal epithelium.

in NPC $[46,47]$. Expression of p53 has also been reported to be deregulated by ubiquitination because of the methylation dependent silencing of UCHL1 - a TSG in NPC [48]. Furthermore hypermethylation of several other TSGs such as retinoic acid receptor $\beta 2$ (RAR $\beta 2$ ), death-associated protein kinase (DAPK), deleted in lung and esophageal cancer 1 (DLEC1) has also been reported in NPC [41, 49-51].

Our established approach was tested here, namely NotI microarray which is a screening method for aberrantly methylated $\mathrm{CpG}$-rich regions in the DNA using methylation sensitive restriction enzymes. It was applied to chromosome 3 , which is one of the regions always affected in NPC as well as in many other epithelial cancers $[52,53]$. With this screening, ten high scoring candidate genes were identified of which ITGA9 was verified to be methylated and downregulated in NPC tissue samples and NPC cell lines at mRNA and protein levels, which correlated to methylation status of its control regions. Methylation of ITGA9 gene promoter was observed in NPC tumor biopsies despite the challenge of contamination by normal stromal tissue. It suggests that ITGA9 gene potentially could have important functions in tumor tissue organization and its epigenetic inactivation appears to be a major mechanism for its loss of expression in NPC.

The ITGA9 gene is located in the 3p21.3-22.2 segment of chromosome 3 [54, 55] and encodes an integrin subunit, $\alpha 9$. This is a 1035 amino acid polypeptide with a large $\mathrm{N}$-terminal extracellular domain with seven conserved repeats, a transmembrane segment and a short C-terminal cytoplasmic tail. The $\alpha 9$ subunit forms heterodimers only with the $\beta 1$ chain forming a unique integrin, $\alpha 9 \beta 1$, widely expressed in the human airway epithelial cells, and binding to a variety of ligands [56]. 
The $\alpha 9 \beta 1$ integrin receptor plays an integral role in different signal transduction pathways controlling cellular proliferation and differentiation. Integrin $\alpha 9 \beta 1$ has been reported to mediate cell migration in glioblastoma [57]. In ITGA9 knockout mice, abnormal proliferation and differentiation of keratinocytes suggest its role in these cellular processes [58]. The role of ITGA9 and its ligands in NPC development deserve further investigation.

Downregulation of ITGA9 has been reported in human papilloma virus associated head and neck squamous cell carcinoma [59], non-small cell lung cancer (NSCLC) $[60,61]$, leukoplakia, lichen planus, and oral squamous cell carcinoma $[62,63]$. Hypermethylation of ITGA9 was found in tumor samples from breast, kidney, cervix, ovary, lung, prostate [30], colorectal cancer [64], hepatocellular carcinoma [65] and premalignant cervical lesions [66]. In another study hypermethylation of ITGA9 at its first intron has been reported to be the major mechanism for its downregulation in breast cancer [67]. Our data is consistent with these findings. Mutations in ITGA9 are a less frequent event while its downregulation is considered to be more important in tumorigenesis [68]. However in contrast to the downregulation of ITGA9 in some cancers it has also been found to be abundantly expressed in small cell lung cancers (SCLC) primary tumors and cell lines where it has been suggested to play a role in metastasis, in the progression to more malignant phenotypes [69] and to poor survival [70]. Similarly integrin $\alpha 9 \beta 1$ expression in breast cancer has also been reported to be associated with poor patient survival, increased cell migration and invasion in the breast cancer cell lines [71].

It is interesting to compare results of this study with the work of Law et al [72]. They investigated methylation pattern of chromosome 3 genes in NPC cell lines, and they described five genes (FBLN2, TMEM45A, ZIC4, GPR149 and ETV5) as epigenetically regulated. We were unable to find these genes to be differentially methylated in NPC samples. This could be because we used NPC tissue samples together with NPC cell lines for the initial screening using NMA on chromosome 3.

We have recently evaluated the potential use of ITGA9 methylation as one of the markers in a multiplex methylation specific PCR assay designed for the early diagnosis of NPC patients from different ethnic and geographic backgrounds. The results show that the assay could identify $91 \%(58 / 64)$ NPC patients with $90 \%$ specificity (18/20) [73]. Our results strongly suggest that in depth studies should be pursued to understand the functional role of ITGA9 downregulation in the development of NPC.

\section{MATERIALS AND METHODS}

\section{Cell lines and clinical samples}

Human NPC cell lines CNE1 (EBV negative, from the Cancer Center, Sun Yat-Sen University, China) and TWO3 (EBV negative, a gift from Dr. Lin CT, National Taiwan
University Hospital) [74] were cultured in IMEM (Gibco) containing $10 \%$ fetal calf serum (FCS). NPC cell line C666-1 (EBV positive, from Dr. Huang DR, the Department of Anatomical and Cellular Pathology and Institute of Molecular Oncology, the Chinese University of Hong Kong, Prince of Wales Hospital, Shatin, New Territories, Hong Kong, China) was cultured in IMEM (Gibco) containing $15 \%$ FCS. The immortalized nasopharyngeal epithelial cell line NP69 (EBV negative, from Dr. Tsao SW, the University of Hong Kong, China) [75] was cultured in keratinocyte serum-free medium (Invitrogen) supplemented with $25 \mu \mathrm{g} / \mathrm{ml}$ bovine pituitary extract, and $0.2 \mathrm{ng} / \mathrm{ml}$ recombinant epidermal growth factor, as suggested by the manufacturer. Cell lines C666-1 and NP69 are authenticated to be of human NPC and NNE origin respectively. C666-1 was also EBV positive. CNE1 and TWO3 are also authenticated to be of human nasopharyngeal epithelial cancer origin, comply with their original profile, but their origin from NPC cannot definitely be verified and they were EBV negative.

Paraffin sections from 20 cases of untreated NPC, and 10 control nasopharyngeal tissues were collected at the Cancer Center, Sun-Yat-Sen University in 2011. For immunostaining, three archival formalin-fixed, paraffinembedded (FFPE) tissue specimens, which contained both NPC tumor tissue and control epithelial tissue, also had been sampled at the Sun-Yat-Sen University Cancer Center (Guangzhou, China) histopathology bank. This study was approved by the Research Ethics Committee of Sun Yat-Sen University Cancer Center, Guangzhou, China (Reference number: YP-2009175) and the regional ethics committee of the Karolinska Institutet, Stockholm, Sweden (Reference number: 00-302).

NPC DNA samples from $36 \mathrm{EBV}$ positive pathology-verified NPC patients and 18 normal volunteers were obtained from Institut Pasteur du Maroc, Casablanca, Morocco in the year 2011 (ethical approval: No. 00-302, Stockholm, Sweden and 2010-02-15, Casablanca, Morocco) for MSP analysis.

\section{DNA and RNA extraction}

DNA was extracted from NPC cell lines, biopsies and control epithelial tissues, and purified by conventional phenol/chloroform and ethanol extraction. Total RNA was extracted by TRIzol ${ }^{\circledR}$ reagent (Invitrogen, Cat\#: 15596-026). All RNA samples were treated with RNAse free DNAse I (Fermentas, Cat\#: EN0521) and cDNA was synthesized using MMLV reverse transcriptase with random hexamers according to the standard protocol provided by the manufacturer (Invitrogen, Cat\#: AM2043).

\section{Screening for methylated $\mathrm{CpG}$-rich regions in gene promoter by NotI microarrays}

NotI microarrays were constructed as previously described [29, 76, 77]. In the present study, a total 
188 putative TSGs were plated in triplicates on glass slides for hybridization screening.

\section{DNA conversion by bisulfite treatment}

DNA samples from NPC patients and controls were processed for bisulfite conversion using EZ DNA Methylation Kit (ZymoResearch, Cat\#: D5001) following the manufacturer's recommendations. Five hundred ng of genomic DNA was used as starting material for bisulfite modification.

\section{5'-aza-C treatment}

NPC cell lines CNE1, TWO3, C666-1 and normal nasopharyngeal epithelium derived cell line NP69 were seeded at $2 \times 10^{5}$ per well in six-well plates and - after 24 hours - cultured with $10 \mu \mathrm{M} 5$ '-aza-C (Sigma-Aldrich). The medium with the added drug was replaced every 24 hour. After four days treatment, DNA was isolated for measuring the methylation status by MSP, and RNA for evaluating restoration of gene expression by Q-PCR, comparing with medium control.

\section{Q-PCR assays}

The first-strand cDNA was used as template for measuring the expression levels of ITGA9 and WNT7A by mRNA quantitative real time PCR (Q-PCR) with the SYBR Green I chemistry (Power SYBR Green PCR Master Mix, CAT\#: 4367659, ABI Inc.). GAPDH was used as internal control. Melting temperature for Q-PCR was $55.5^{\circ} \mathrm{C}, 58^{\circ} \mathrm{C}$ and $51.5^{\circ} \mathrm{C}$ for ITGA9, WNT7A and GAPDH respectively. The primer sequences used for Q-PCR are shown in Table 2. The relative expression level was determined as $2-\Delta \Delta \mathrm{Ct}$. Data are presented as the expression level relative to the calibrator control sample.

\section{Immunostaining}

Primary antibodies against ITGA9 (1:100 dilution; Cat\#: sc-68864, Santa Cruz Biotechnology, Inc.) and WNT7A (1:250 dilution; Cat\#: HPA015719, Atlas Antibodies) were used. Briefly, tissue sections were de-waxed, incubated with hydrogen peroxide for 10 minutes, incubated in retrieval buffer solution for antigen recovery, blocked with normal serum for 10 minutes and incubated with a primary antibody for 60 minutes, followed by detection using a Catalyzed Signal Amplification Kit (DAKO); signals were visualized using diaminobenzidine. Non-immune goat or rabbit serum was substituted for the primary antibody as a negative control.

\section{Sequencing of clones derived from bisulfite converted DNA}

Bisulfite modified DNA was subjected to PCR with primers flanking the targeted methylation-specific PCR regions. The primers used for bisulfite sequencing of ITGA9 and WNT7A were designed using Methprimer [78] online software and are shown in Table 2. PCR products were purified using Invisorb ${ }^{\circledR}$ Spin DNA Extraction Kit (Invitek, Cat\#: 1020110200). The purified PCR products were cloned in E.coli TOP10 using CloneJET PCR Cloning Kit (Fermentas, Cat\#: K1231). Clones were sequenced using pJET1.2 reverse sequencing primer, 24-mer (Fermentas, Cat\#: SO511), a BigDye Terminator v3.1 Cycle Sequencing Kit (Applied Biosystems, Cat\#: PN4337035) and 3730 DNA Analyzer (Applied Biosystems). The manufacturers' recommendations were followed during all the steps for bisulfite sequencing.

\section{Pyrosequencing of bisulfite converted DNA}

Two subsets of CpGs within or close to the ITGA9promoter region sequenced from the clones (above; Figure 4) were used for pyrosequencing after bisulfiteconversion. For pyrosequencing DNAs from same set of NPC tissue and NNE samples were used as in the sequencing of clones. They included five NPC tumors and two control nasopharyngeal epithelial biopsies. The bisulfite pyrosequencing was performed according to the Pyrosequencing Assay Design Software v2.0 (QIAGEN), details of employed sequences are provided in Table 2. Two $\mu$ l of bisulfite modified genomic DNA ( 20 ng) was used as a template in PCRs performed with the PyroMark PCR kit (QIAGEN, Cat\#: 978703) following the manufacturer's recommendations. A melting temperature of $58^{\circ} \mathrm{C}$ was used for both the assays. PCR amplifications were performed in $50 \mu \mathrm{l}$ volumes. The entire PCR product, $4 \mu \mathrm{M}$ of the respective sequencing primer and $2 \mu \mathrm{l}$ of streptavidin sepharose highperformance beads (GE Healthcare, Cat\#: 17-113-01), were used for bisulfite pyrosequencing performed with the PSQ 96 ID system with enzymes and substrates from the PyroMark Gold Q96 reagent kit (QIAGEN, Cat\#: 972804). PyroMark Q96 ID software 2.5.8.15 (QIAGEN) was used for data analysis.

\section{Methylation specific PCR (MSP)}

The sequences of PCR primers specific for methylated ITGA9 and WNT7A [79] and the primers for $\beta$-ACTIN that served as a quality control to amplify bisulfite-converted DNA without distinguishing between methylated and unmethylated CpGs are given in Table 2. For PCR reaction, $4 \mu \mathrm{l}$ of bisulfite-modified DNA (40 ng) was added in a final volume of $25 \mu \mathrm{l}$ of PCR mixture containing $1.8 \times$ PCR buffer, $5 \mathrm{mM} \mathrm{MgCl}_{2}, 100 \mathrm{pmol}$ deoxynucleotide triphosphates, primers (100 pmol each per reaction) and one unit of Taq Platinum (Invitrogen). PCR amplifications were performed at $95^{\circ} \mathrm{C}$ for $3 \mathrm{~min}$, followed by 4 cycles at $94^{\circ} \mathrm{C}$ for $1 \mathrm{~min}, 60^{\circ} \mathrm{C}$ for $30 \mathrm{~s}$, and $72^{\circ} \mathrm{C}$ for $45 \mathrm{~s}$, which was then followed by 28 amplification cycles at $94^{\circ} \mathrm{C}$ for $1 \mathrm{~min}, 56^{\circ} \mathrm{C}$ for $1 \mathrm{~min}$, and $72^{\circ} \mathrm{C}$ for $45 \mathrm{~s}$. 


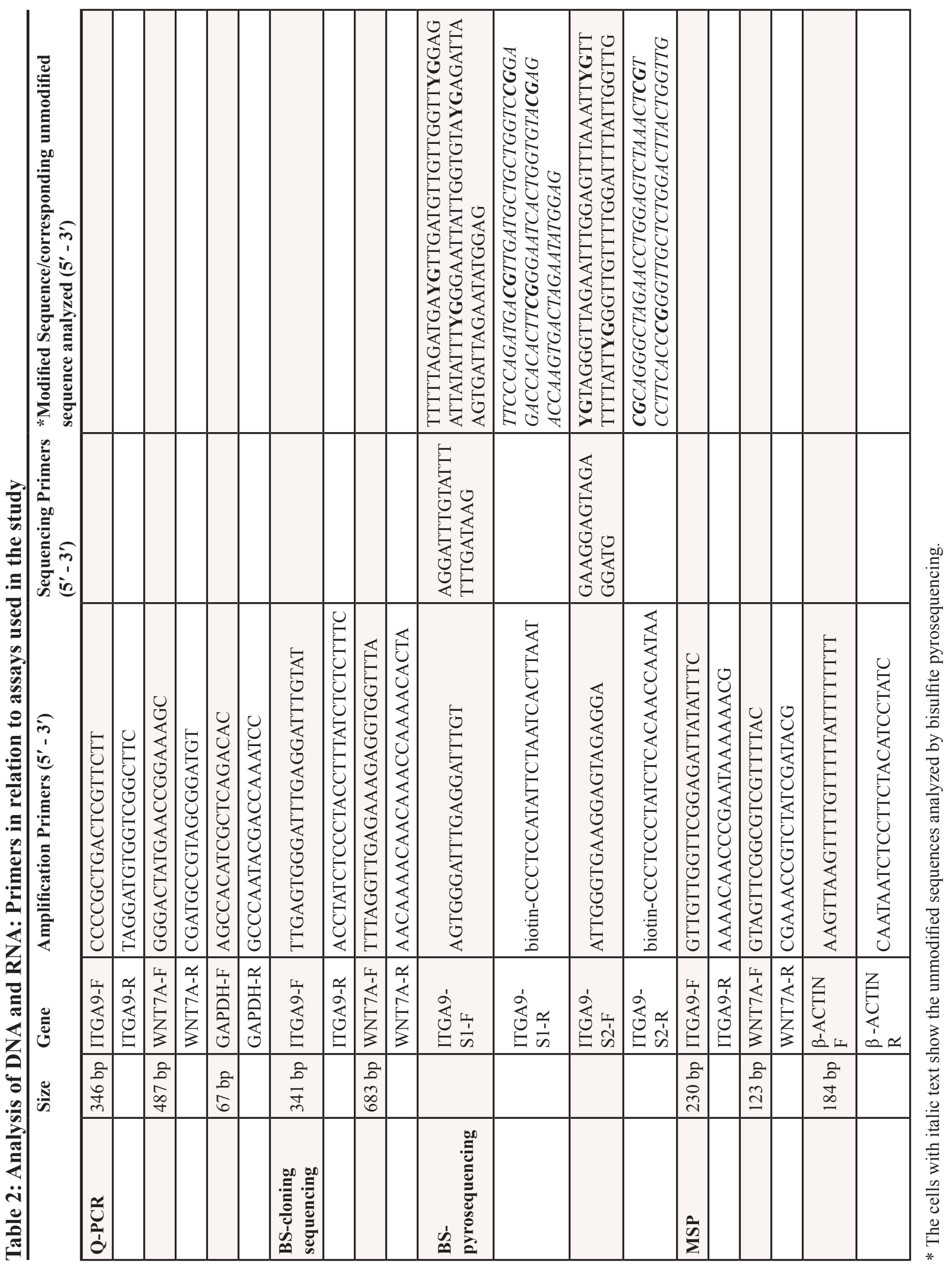


The final elongation step was performed at $72^{\circ} \mathrm{C}$ for $4 \mathrm{~min}$. MSP products were analyzed by $2 \%$ agarose gel electrophoresis stained with ethidium bromide.

\section{ACKNOWLEDGMENTS}

Thanks to Dr. Lin CT, National Taiwan University Hospital and Dr. Huang DR, the Department of Anatomical and Cellular Pathology and Institute of Molecular Oncology, The Chinese University of Hong Kong, Prince of Wales Hospital, Shatin, New Territories, Hong Kong, China for providing Human NPC cell lines TWO3 and C666-1.

\section{CONFLICTS OF INTEREST}

No potential conflict of interest existed.

\section{GRANT SUPPORT}

This study was supported by grants from Cancerfonden, Cancerföreningen in Stockholm, National Natural Science Foundation of China (No. 81202135) and a fellowship from the Project for the Development of University of Balochistan, Quetta, Pakistan. The funders had no role in study design, data collection and analysis, decision to publish, or preparation of the manuscript.

\section{REFERENCES}

1. Licitra L, Bernier J, Cvitkovic E, Grandi C, Spinazze S, Bruzzi P, Gatta G, Molinari R. Cancer of the nasopharynx. Critical reviews in oncology/hematology. 2003; 45:199-213.

2. Shanmugaratnam K, Sobin LH. The World Health Organization histological classification of tumours of the upper respiratory tract and ear. A commentary on the second edition. Cancer. 1993; 71:2689-2697.

3. Tabuchi K, Nakayama M, Nishimura B, Hayashi K, Hara A. Early detection of nasopharyngeal carcinoma. International journal of otolaryngology. 2011; 2011:638058.

4. Chang ET, Adami HO. The enigmatic epidemiology of nasopharyngeal carcinoma. Cancer epidemiology, biomarkers \& prevention : a publication of the American Association for Cancer Research, cosponsored by the American Society of Preventive Oncology. 2006; 15:1765-1777.

5. Armstrong RW, Kannan Kutty M, Dharmalingam SK, Ponnudurai JR. Incidence of nasopharyngeal carcinoma in Malaysia, 1968-1977. British journal of cancer. 1979; 40:557-567.

6. Devi BC, Pisani P, Tang TS, Parkin DM. High incidence of nasopharyngeal carcinoma in native people of Sarawak, Borneo Island. Cancer epidemiology, biomarkers
\& prevention : a publication of the American Association for Cancer Research, cosponsored by the American Society of Preventive Oncology. 2004; 13:482-486.

7. Lee AWM, Foo W, Mang O, Sze WM, Chappell R, Lau WH, Ko WM. Changing epidemiology of nasopharyngeal carcinoma in Hong Kong over a 20-year period (1980-99): An encouraging reduction in both incidence and mortality. International Journal of Cancer. 2003; 103:680-685.

8. Nguyen-Van D, Ernberg I, Phan-Thi Phi P, Tran-Thi C, $\mathrm{Hu}$ L. Epstein-Barr virus genetic variation in Vietnamese patients with nasopharyngeal carcinoma: full-length analysis of LMP1. Virus genes. 2008; 37:273-281.

9. Chi KH, Chang YC, Guo WY, Leung MJ, Shiau CY, Chen SY, Wang LW, Lai YL, Hsu MM, Lian SL, Chang $\mathrm{CH}$, Liu TW, Chin YH, Yen SH, Perng $\mathrm{CH}$, Chen KY. A phase III study of adjuvant chemotherapy in advanced nasopharyngeal carcinoma patients. International journal of radiation oncology, biology, physics. 2002; 52:1238-1244.

10. Agulnik M, Siu LL. State-of-the-art management of nasopharyngeal carcinoma: current and future directions. British journal of cancer. 2005; 92:799-806.

11. AJCC Cancer Staging Manual. 2010; New York: Springer.

12. Wei WI, Kwong DL. Current management strategy of nasopharyngeal carcinoma. Clinical and experimental otorhinolaryngology. 2010; 3:1-12.

13. Suva ML, Riggi N, Bernstein BE. Epigenetic reprogramming in cancer. Science. 2013; 339:1567-1570.

14. Baylin SB, Herman JG, Graff JR, Vertino PM, Issa JP. Alterations in DNA methylation: a fundamental aspect of neoplasia. Advances in cancer research. 1998; 72:141-196.

15. Aryee MJ, Liu W, Engelmann JC, Nuhn P, Gurel M, Haffner MC, Esopi D, Irizarry RA, Getzenberg RH, Nelson WG, Luo J, Xu J, Isaacs WB, Bova GS, Yegnasubramanian S. DNA methylation alterations exhibit intraindividual stability and interindividual heterogeneity in prostate cancer metastases. Science translational medicine. 2013; 5:169ra110.

16. Feinberg AP, Ohlsson R, Henikoff S. The epigenetic progenitor origin of human cancer. Nature reviews Genetics. 2006; 7:21-33.

17. Kulis M, Esteller M. DNA methylation and cancer. Advances in genetics. 2010; 70:27-56.

18. Chou J, Lin YC, Kim J, You L, Xu Z, He B, Jablons DM. Nasopharyngeal carcinoma-review of the molecular mechanisms of tumorigenesis. Head \& neck. 2008; 30:946-963.

19. Lo KW, Huang DP. Genetic and epigenetic changes in nasopharyngeal carcinoma. Seminars in cancer biology. 2002; 12:451-462.

20. Tao Q, Chan AT. Nasopharyngeal carcinoma: molecular pathogenesis and therapeutic developments. Expert reviews in molecular medicine. 2007; 9:1-24. 
21. Tian F, Yip SP, Kwong DL, Lin Z, Yang Z, Wu VW. Promoter hypermethylation of tumor suppressor genes in serum as potential biomarker for the diagnosis of nasopharyngeal carcinoma. Cancer epidemiology. 2013; 37:708-713.

22. Yang X, Dai W, Kwong DL, Szeto CY, Wong EH, Ng WT, Lee AW, Ngan RK, Yau CC, Tung SY, Lung ML. Epigenetic markers for noninvasive early detection of nasopharyngeal carcinoma by methylation-sensitive high resolution melting. International journal of cancer Journal international du cancer. 2015; 136:E127-135.

23. Schulz W. Qualified promise: DNA methylation assays for the detection and classification of human cancers. Journal of biomedicine \& biotechnology. 2005; 2005:227-229.

24. Rush LJ, Plass C. Restriction landmark genomic scanning for DNA methylation in cancer: past, present, and future applications. Analytical biochemistry. 2002; 307:191-201.

25. Kantlehner M, Kirchner R, Hartmann P, Ellwart JW, Alunni-Fabbroni M, Schumacher A. A high-throughput DNA methylation analysis of a single cell. Nucleic acids research. 2011; 39:e44.

26. Gitan RS, Shi H, Chen CM, Yan PS, Huang TH. Methylation-specific oligonucleotide microarray: a new potential for high-throughput methylation analysis. Genome research. 2002; 12:158-164.

27. Ahluwalia A, Yan P, Hurteau JA, Bigsby RM, Jung SH, Huang TH, Nephew KP. DNA methylation and ovarian cancer. I. Analysis of $\mathrm{CpG}$ island hypermethylation in human ovarian cancer using differential methylation hybridization. Gynecologic oncology. 2001; 82:261-268.

28. Zabarovsky ER, Lerman MI, Minna JD. Tumor suppressor genes on chromosome $3 p$ involved in the pathogenesis of lung and other cancers. Oncogene. 2002; 21:6915-6935.

29. Li J, Protopopov A, Wang F, Senchenko V, Petushkov V, Vorontsova O, Petrenko L, Zabarovska V, Muravenko O, Braga E, Kisselev L, Lerman MI, Kashuba V, Klein G, Ernberg I, Wahlestedt C, et al. NotI subtraction and NotIspecific microarrays to detect copy number and methylation changes in whole genomes. Proceedings of the National Academy of Sciences of the United States of America. 2002; 99:10724-10729.

30. Pavlova TV, Kashuba VI, Muravenko OV, Yenamandra SP, Ivanova TA, Zabarovska VI, Rakhmanaliev ER, Petrenko LA, Pronina IV, Loginov VI, Yurkevich OY, Kisselev LL, Zelenin AV, Zabarovsky ER. Use of NotI microarrays in analysis of epigenetic and structural changes in epithelial tumor genomes by the example of human chromosome 3. Mol Biol+. 2009; 43:313-320.

31. Agulnik M, Epstein JB. Nasopharyngeal carcinoma: current management, future directions and dental implications. Oral oncology. 2008; 44:617-627.

32. Raghupathy R, Hui EP, Chan AT. Epstein-Barr virus as a paradigm in nasopharyngeal cancer: from lab to clinic. American Society of Clinical Oncology educational book / ASCO American Society of Clinical Oncology Meeting. 2014; :149-153.

33. Ayadi W, Khabir A, Hadhri-Guiga B, Fki L, Toumi N, Siala W, Charfi S, Fendri A, Makni H, Boudawara T, Ghorbel A, Gargouri A, Jlidi R, Gargouri R, Busson P, Drira M, et al. [North African and Southeast Asian nasopharyngeal carcinomas: between the resemblance and the dissemblance]. Bulletin du cancer. 2010; 97:475-482.

34. Kwok WK, Pang JC, Lo KW, Ng HK. Role of the RARRES1 gene in nasopharyngeal carcinoma. Cancer genetics and cytogenetics. 2009; 194:58-64.

35. Flower K, Thomas D, Heather J, Ramasubramanyan S, Jones S, Sinclair AJ. Epigenetic control of viral life-cycle by a DNA-methylation dependent transcription factor. PloS one. 2011; 6:e25922.

36. Cheng Y, Poulos NE, Lung ML, Hampton G, Ou B, Lerman MI, Stanbridge EJ. Functional evidence for a nasopharyngeal carcinoma tumor suppressor gene that maps at chromosome 3p21.3. Proceedings of the National Academy of Sciences of the United States of America. 1998; 95:3042-3047.

37. Hesson LB, Cooper WN, Latif F. Evaluation of the 3 p21.3 tumour-suppressor gene cluster. Oncogene. 2007; 26:7283-7301.

38. Lerman MI, Minna JD. The 630-kb lung cancer homozygous deletion region on human chromosome 3p21.3: identification and evaluation of the resident candidate tumor suppressor genes. The International Lung Cancer Chromosome 3p21.3 Tumor Suppressor Gene Consortium. Cancer research. 2000; 60:6116-6133.

39. Dammann R, Li C, Yoon JH, Chin PL, Bates S, Pfeifer GP. Epigenetic inactivation of a RAS association domain family protein from the lung tumour suppressor locus 3p21.3. Nature genetics. 2000; 25:315-319.

40. Chen J, Fu L, Zhang LY, Kwong DL, Yan L, Guan XY. Tumor suppressor genes on frequently deleted chromosome $3 p$ in nasopharyngeal carcinoma. Chinese journal of cancer. 2012; 31:215-222.

41. Li LL, Shu XS, Wang ZH, Cao Y, Tao Q. Epigenetic disruption of cell signaling in nasopharyngeal carcinoma. Chinese journal of cancer. 2011; 30:231-239.

42. Kaneda A, Matsusaka K, Aburatani H, Fukayama M. Epstein-Barr virus infection as an epigenetic driver of tumorigenesis. Cancer research. 2012; 72:3445-3450.

43. Li L, Zhang Y, Guo BB, Chan FK, Tao Q. Oncogenic induction of cellular high $\mathrm{CpG}$ methylation by Epstein-Barr virus in malignant epithelial cells. Chinese journal of cancer. 2014; 33:604-608.

44. Sun Y, Hegamyer G, Colburn NH. Nasopharyngeal carcinoma shows no detectable retinoblastoma susceptibility gene alterations. Oncogene. 1993; 8:791-795.

45. Spruck $\mathrm{CH}$ 3rd, Tsai YC, Huang DP, Yang AS, Rideout WM, 3rd, Gonzalez-Zulueta M, Choi P, Lo KW, 
$\mathrm{Yu}$ MC, Jones PA. Absence of p53 gene mutations in primary nasopharyngeal carcinomas. Cancer research. 1992; 52:4787-4790.

46. Lo KW, Huang DP, Lau KM. p16 gene alterations in nasopharyngeal carcinoma. Cancer research. 1995; 55:2039-2043.

47. Lo KW, Kwong J, Hui AB, Chan SY, To KF, Chan AS, Chow LS, Teo PM, Johnson PJ, Huang DP. High frequency of promoter hypermethylation of RASSF1A in nasopharyngeal carcinoma. Cancer research. 2001; 61:3877-3881.

48. Li L, Tao Q, Jin H, van Hasselt A, Poon FF, Wang X, Zeng MS, Jia WH, Zeng YX, Chan AT, Cao Y. The tumor suppressor UCHL1 forms a complex with p53/MDM2/ARF to promote $\mathrm{p} 53$ signaling and is frequently silenced in nasopharyngeal carcinoma. Clinical cancer research: an official journal of the American Association for Cancer Research. 2010; 16:2949-2958.

49. Kwong J, Lo KW, To KF, Teo PM, Johnson PJ, Huang DP. Promoter hypermethylation of multiple genes in nasopharyngeal carcinoma. Clinical cancer research: an official journal of the American Association for Cancer Research. 2002; 8:131-137.

50. Ayadi W, Karray-Hakim H, Khabir A, Feki L, Charfi S, Boudawara T, Ghorbel A, Daoud J, Frikha M, Busson P, Hammami A. Aberrant methylation of p16, DLEC1, BLU and E-cadherin gene promoters in nasopharyngeal carcinoma biopsies from Tunisian patients. Anticancer research. 2008; 28:2161-2167.

51. Fendri A, Masmoudi A, Khabir A, Sellami-Boudawara T, Daoud J, Frikha M, Ghorbel A, Gargouri A, MokdadGargouri R. Inactivation of RASSF1A, RARbeta2 and DAP-kinase by promoter methylation correlates with lymph node metastasis in nasopharyngeal carcinoma. Cancer biology \& therapy. 2009; 8:444-451.

52. Lo KW, Teo PM, Hui AB, To KF, Tsang YS, Chan SY, Mak KF, Lee JC, Huang DP. High resolution allelotype of microdissected primary nasopharyngeal carcinoma. Cancer research. 2000; 60:3348-3353.

53. Chan AS, To KF, Lo KW, Mak KF, Pak W, Chiu B, Tse GM, Ding M, Li X, Lee JC, Huang DP. High frequency of chromosome $3 p$ deletion in histologically normal nasopharyngeal epithelia from southern Chinese. Cancer research. 2000; 60:5365-5370.

54. Xiong W, Zeng ZY, Xia JH, Xia K, Shen SR, Li XL, Hu DX, Tan C, Xiang JJ, Zhou J, Deng H, Fan SQ, Li WF, Wang R, Zhou M, Zhu SG, et al. A susceptibility locus at chromosome 3p21 linked to familial nasopharyngeal carcinoma. Cancer research. 2004; 64:1972-1974.

55. Ng CC, Yew PY, Puah SM, Krishnan G, Yap LF, Teo SH, Lim PV, Govindaraju S, Ratnavelu K, Sam CK, Takahashi A, Kubo M, Kamatani N, Nakamura Y, Mushiroda T. A genome-wide association study identifies ITGA9 conferring risk of nasopharyngeal carcinoma. Journal of human genetics. 2009; 54:392-397.
56. Takada Y, Ye X, Simon S. The integrins. Genome biology. 2007; 8:215.

57. Veeravalli KK, Ponnala S, Chetty C, Tsung AJ, Gujrati M, Rao JS. Integrin alpha9beta1-mediated cell migration in glioblastoma via SSAT and Kir4.2 potassium channel pathway. Cellular signalling. 2012; 24:272-281.

58. Singh P, Chen C, Pal-Ghosh S, Stepp MA, Sheppard D, Van De Water L. Loss of integrin alpha9beta1 results in defects in proliferation, causing poor re-epithelialization during cutaneous wound healing. The Journal of investigative dermatology. 2009; 129:217-228.

59. Ghosh A, Ghosh S, Maiti GP, Sabbir MG, Zabarovsky ER, Roy A, Roychoudhury S, Panda CK. Frequent alterations of the candidate genes hMLH1, ITGA9 and RBSP3 in early dysplastic lesions of head and neck: clinical and prognostic significance. Cancer science. 2010; 101:1511-1520.

60. Anedchenko EA, Dmitriev AA, Krasnov GS, Kondrat'eva TT, Kopantsev EP, Vinogradova TV, Zinov'eva MV, Zborovskaia IB, Polotskii BE, Sakharova OV, Kashuba VI, Zabarovskii ER, Senchenko VN. [Down-regulation of RBSP3/CTDSPL, NPRL2/G21, RASSF1A, ITGA9, HYAL1 and HYAL2 genes in non-small cell lung cancer]. Molekuliarnaia biologiia. 2008; 42:965-976.

61. Dmitriev AA, Kashuba VI, Haraldson K, Senchenko VN, Pavlova TV, Kudryavtseva AV, Anedchenko EA, Krasnov GS, Pronina IV, Loginov VI, Kondratieva TT, Kazubskaya TP, Braga EA, Yenamandra SP, Ignatjev I, Ernberg I, et al. Genetic and epigenetic analysis of nonsmall cell lung cancer with NotI-microarrays. Epigenetics: official journal of the DNA Methylation Society. 2012; 7:502-513.

62. Hakkinen L, Kainulainen T, Salo T, Grenman R, Larjava H. Expression of integrin alpha9 subunit and tenascin in oral leukoplakia, lichen planus, and squamous cell carcinoma. Oral diseases. 1999; 5:210-217.

63. Roy S, Bingle L, Marshall JF, Bass R, Ellis V, Speight PM, Whawell SA. The role of alpha9betal integrin in modulating epithelial cell behaviour. Journal of oral pathology \& medicine : official publication of the International Association of Oral Pathologists and the American Academy of Oral Pathology. 2011; 40:755-761.

64. Gerashchenko GV, Gordiyuk VV, Skrypkina IY, Kvasha SM, Kolesnik OO, Ugryn DD, Pavlova TV, Zabarovsky ER, Rynditch AV, Kashuba VI. Screening of epigenetic and genetic disturbances of human chromosome 3 genes in colorectal cancer. Ukrainskii biokhimicheskii zhurnal. 2009; 81:81-87.

65. Li JL, Fei Q, Yu J, Zhang HY, Wang P, Zhu JD. Correlation between methylation profile of promoter cpg islands of seven metastasis-associated genes and their expression states in six cell lines of liver origin. Ai zheng $=$ Aizheng $=$ Chinese journal of cancer. 2004; 23:985-991. 
66. Mitra S, Mazumder Indra D, Bhattacharya N, Singh RK, Basu PS, Mondal RK, Roy A, Zabarovsky ER, Roychoudhury S, Panda CK. RBSP3 is frequently altered in premalignant cervical lesions: clinical and prognostic significance. Genes, chromosomes \& cancer. 2010; 49:155-170.

67. Mostovich LA, Prudnikova TY, Kondratov AG, Loginova D, Vavilov PV, Rykova VI, Sidorov SV, Pavlova TV, Kashuba VI, Zabarovsky ER, Grigorieva EV. Integrin alpha9 (ITGA9) expression and epigenetic silencing in human breast tumors. Cell adhesion \& migration. $2011 ; 5: 395-401$.

68. Hoye AM, Couchman JR, Wewer UM, Fukami K, Yoneda A. The newcomer in the integrin family: integrin alpha9 in biology and cancer. Adv Biol Regul. 2012; 52:326-339.

69. Hibi K, Yamakawa K, Ueda R, Horio Y, Murata Y, Tamari M, Uchida K, Takahashi T, Nakamura Y, Takahashi T. Aberrant upregulation of a novel integrin alpha subunit gene at 3 p21.3 in small cell lung cancer. Oncogene. 1994; 9:611-619.

70. Gupta SK, Oommen S, Aubry MC, Williams BP, Vlahakis NE. Integrin alpha9betal promotes malignant tumor growth and metastasis by potentiating epithelialmesenchymal transition. Oncogene. 2013; 32:141-150.

71. Allen MD, Vaziri R, Green M, Chelala C, Brentnall AR, Dreger S, Vallath S, Nitch-Smith H, Hayward J, Carpenter R, Holliday DL, Walker RA, Hart IR, Jones JL. Clinical and functional significance of alpha9betal integrin expression in breast cancer: a novel cell-surface marker of the basal phenotype that promotes tumour cell invasion. The Journal of pathology. 2011; 223:646-658.

72. Law EW, Cheung AK, Kashuba VI, Pavlova TV, Zabarovsky ER, Lung HL, Cheng Y, Chua D, Lai-Wan Kwong D, Tsao SW, Sasaki T, Stanbridge EJ, Lung ML. Anti-angiogenic and tumor-suppressive roles of candidate tumor-suppressor gene, Fibulin-2, in nasopharyngeal carcinoma. Oncogene. 2012; 31:728-738.
73. Nawaz I, Moumad K, Martorelli D, Ennaji MM, Zhou X, Zhang Z, Dolcetti R, Khyatti M, Ernberg I and Hu LF. Detection of nasopharyngeal carcinoma in Morocco (North Africa) using a multiplex methylation-specific PCR biomarker assay. Clin Epigenetics. 2015; 7(1):89. doi: 10.1186/ s13148-015-0119-8. eCollection 2015

74. Lin CT, Chan WY, Chen W, Huang HM, Wu HC, Hsu MM, Chuang SM, Wang CC. Characterization of seven newly established nasopharyngeal carcinoma cell lines. Laboratory investigation; a journal of technical methods and pathology. 1993; 68:716-727.

75. Tsao SW, Wang X, Liu Y, Cheung YC, Feng H, Zheng Z, Wong N, Yuen PW, Lo AK, Wong YC, Huang DP. Establishment of two immortalized nasopharyngeal epithelial cell lines using SV40 large T and HPV16E6/E7 viral oncogenes. Biochimica et biophysica acta. 2002; 1590:150-158.

76. Dunwell TL, Hesson LB, Pavlova T, Zabarovska V, Kashuba V, Catchpoole D, Chiaramonte R, Brini AT, Griffiths M, Maher ER, Zabarovsky E, Latif F. Epigenetic analysis of childhood acute lymphoblastic leukemia. Epigenetics: official journal of the DNA Methylation Society. 2009; 4:185-193.

77. Senchenko VN, Anedchenko EA, Kondratieva TT, Krasnov GS, Dmitriev AA, Zabarovska VI, Pavlova TV, Kashuba VI, Lerman MI, Zabarovsky ER. Simultaneous down-regulation of tumor suppressor genes RBSP3/ CTDSPL, NPRL2/G21 and RASSF1A in primary nonsmall cell lung cancer. BMC cancer. 2010; 10:75.

78. Li LC, Dahiya R. MethPrimer: designing primers for methylation PCRs. Bioinformatics. 2002; 18:1427-1431.

79. Matsubayashi H, Canto M, Sato N, Klein A, Abe T, Yamashita K, Yeo CJ, Kalloo A, Hruban R, Goggins M. DNA methylation alterations in the pancreatic juice of patients with suspected pancreatic disease. Cancer research. 2006; 66:1208-1217. 